\title{
Monetary Policy Implementation in the Context of International Integration during the Period 2011-2020
}

TRÀN HUY HOÀNG

University of Economics HCMC - hoangtn@ueh.edu.vn LIẼU THU TRÚC

Sóc Trăng Finance Department - lieuthutruc@yahoo.com NGUYẼ̃N HŨ̃U HUÂN

University of Economics HCMC - huannguyen@ueh.edu.vn

\begin{tabular}{|c|c|}
\hline ARTICLE INFO & ABSTRACT \\
\hline 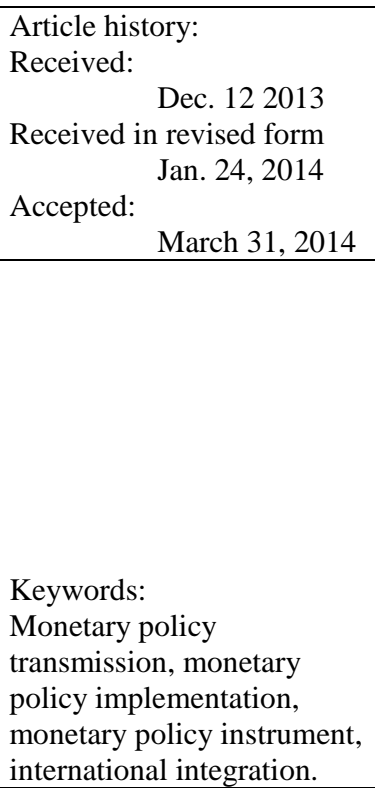 & $\begin{array}{l}\text { The research tries to systematize basic problems with implementation } \\
\text { of monetary policy, provide an overall estimate of the implementation } \\
\text { of this policy by the SBV over periods, test and measure monetary } \\
\text { policy transmission to identify major regulatory instruments, and } \\
\text { suggest measures to maximize effects of the transmission mechanism } \\
\text { of the monetary policy from } 2014 \text { to } 2020 \text { when Vietnam gradually } \\
\text { integrates into the world economy. The research combines the } \\
\text { descriptive statistics and VAR model to analyze each specific target } \\
\text { in the period from } 1990 \text { to present time. The results show that the SBV } \\
\text { has changed to employment of indirect instruments from direct ones } \\
\text { and reduced commands or directions as an administrative body. The } \\
\text { monetary policy in the past, however, was not very effective, which } \\
\text { showed itself in the fact that changes in money supply did not produce } \\
\text { strong effects on such variables as inflation and gross output. Among } \\
\text { instruments for the monetary policy, exchange rate and refinancing } \\
\text { rate are considered important in curbing inflation, and required reserve } \\
\text { has great effects on economic growth, while the research finds no } \\
\text { evidence of effects of credit limit set by the SBV on macroeconomic } \\
\text { variables. }\end{array}$ \\
\hline
\end{tabular}




\section{INTRODUCTION}

Economically, Vietnam is currently a member of UN, WTO, IMF, WB, ADB, APEC, and ASEAN. The country has engaged in multilateral free trade agreements with South Korea, Japan and China and also signed an agreement with Japan on bilateral economic partnership. For Vietnam's monetary banking sector, the integration process is associated with the liberalization of financial market, providing both opportunities and challenges.

In addition to the challenges that banking institutions must overcome when competing for more market share, there are major challenges facing SBV when controlling capital flows, money supply, interest rate, and exchange rate, etc. under sensitive impacts of the international financial markets as well as developments of demand for money, which become more and more complicated due to the increasing diverse in activities of the domestic financial market.

\section{RESEARCH OBJECTIVES}

The overall objective of the study is to review the implementation of the SBV's monetary policy over periods from 1990 to this time, to test and measure the monetary policy transmission in economic governance in Vietnam by considering the transmission through regulatory instruments employed by the SBV in the implementation of monetary policy, thereby identifying essential ones to propose solutions that maximize the effectiveness of the monetary policy transmission in the context of international integration up to 2020. The specific objectives include the followings:

- Systematizing the basics of monetary policy implementation;

- Assessing the SBV's implementation of monetary policy through each stage of development and international integration from 1990 to present;

- Testing and measuring the transmission of monetary policy to the economy; and

- Proposing solutions to improve the shortcomings in monetary policy implementation, which helps maximize the effectiveness of monetary transmission.

\section{THEORETICAL BASES AND METHODOLOGY}

\section{a. Theoretical Background and Analytical Framework:}

- Overview of Monetary Policy:

Monetary policy is widely acknowledged as one of the two important macroeconomic policies (besides fiscal policy, which helps authorities achieve economic goals). 
Monetary policy, according to FED, is considered as actions influencing the availability, cost of money and credit to attain the objectives selected by the Congress, whereas ECB regards the policy as actions taken by central bank by employing policy instruments to reach the goals or specifically, to stabilize the exchange rate. According to Article 3 of the Vietnam State Bank Law (No. 46/2010/QH12 dated June 16, 2010), monetary policy comprises national monetary decisions made by authorized body, including those on stabilization of currency value, represented by target inflation rate, and employment of monetary instruments and measures to achieve its objectives.

Implementation of monetary policy is the SBV's duty while coordinating all activities relating to national monetary issues after the draft monetary policy is approved by the Congress. This requires thinking ability and creativity of the central bank in its mixing and combining monetary instruments flexibly but cautiously enough to implement national monetary objectives as stipulated by the Government.

- Targets of Policy Implementation:

+ The ultimate target of monetary policy adopted by almost all countries is to stabilize currency value, thereby supporting economic growth and creating jobs.

+ Intermediate targets of monetary policy are often to examine the response of the economy to timely make necessary adjustments to achieve the ultimate target. Criteria for adopting intermediate targets by central banks comprise a high and stable correlation with the ultimate target, a possibility of being accurately measured, and the quality of being efficiently controlled by the central bank (Burton, 2009). Compliant with those criteria, the intermediate targets of monetary policy are often the total volume of money supply (M1, M2 or M3) or the market interest rate (short- and long-term ones). These cannot simultaneously be used as the targets of this kind, for choosing the money supply as the main goal will lose control of the interest rate and vice versa (Smitha, 2010).

+ Operational targets are, for one thing, to provide guidelines that allow monetary authorities to make daily decisions, and for another, to inform the market of the status of monetary policy implementation by the central bank. Criteria of operational targets include their close and stable relationships with selected intermediate targets, possibility of being measured by central bank; and quick reaction to impacts of monetary policy instruments. Based on these standards, frequently selected operational targets are: base or reserve money of the intermediary banks, interbank interest rate, open market rate and Treasury bill rate. 


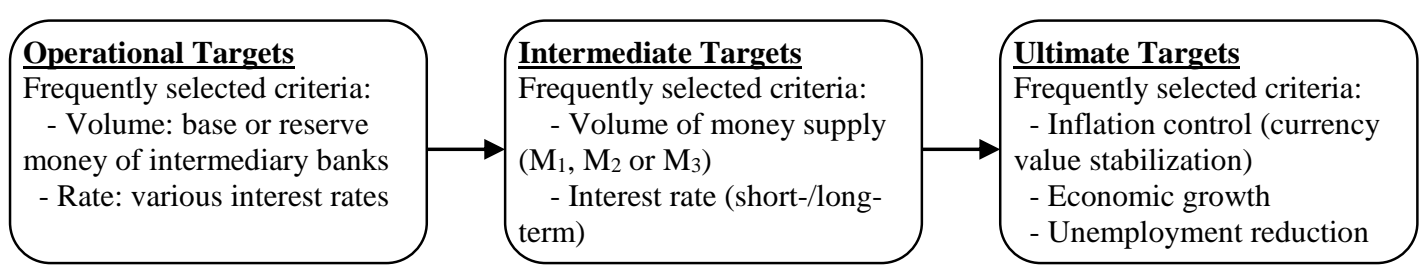

Figure 1: System of Monetary Policy Targets

Regarding instruments of monetary policy stipulated in Article 10, Vietnam State Bank Law, the governor of SBV decides the use of instruments of national monetary policy, including refinancing rate, interest rate, exchange rate, required reserve, openmarket operation and its tools, and other measures prescribed by the Government. Each instrument has its own pros and cons and each, after employed to influence the economy (i.e. to impact trade in money that affects the capital turnover of commercial banks and changes money base in the market including currency circulating in the public and reserves held in the banking system, and thereby indirectly influencing market interest rate) has certain lags.

For that reason, the implementing role of the central bank is crucial, requiring a full knowledge of the operational mechanisms, strengths and weaknesses of each instrument, and the transmission mechanism to harmoniously coordinate and appropriately combine different instruments at different scales and levels. Empirically, Kuttner \& Mosser (2002) and Clinton \& Engert (2000) indicated that the effectiveness of monetary policy depends critically on ability of policy makers to assess on how the timing and effectiveness of the monetary-policy implementation through the transmission channels will affect economic activities and price control.

Transmission mechanism of monetary policy can be generally understood as the process of using monetary policy instruments to influence operational targets altering the money supply and thereby achieving ultimate targets (inflation control, economic growth and reasonable unemployment rate). The desirable characteristics concerning this include (1) simple and transparent monetary policy targets that support easy understanding and implementation, (2) small and gradual changes and observation of gradual response of the economy, (3) risk reduction for financial institutions, and (4) cost reduction for both the central bank and its partners. 


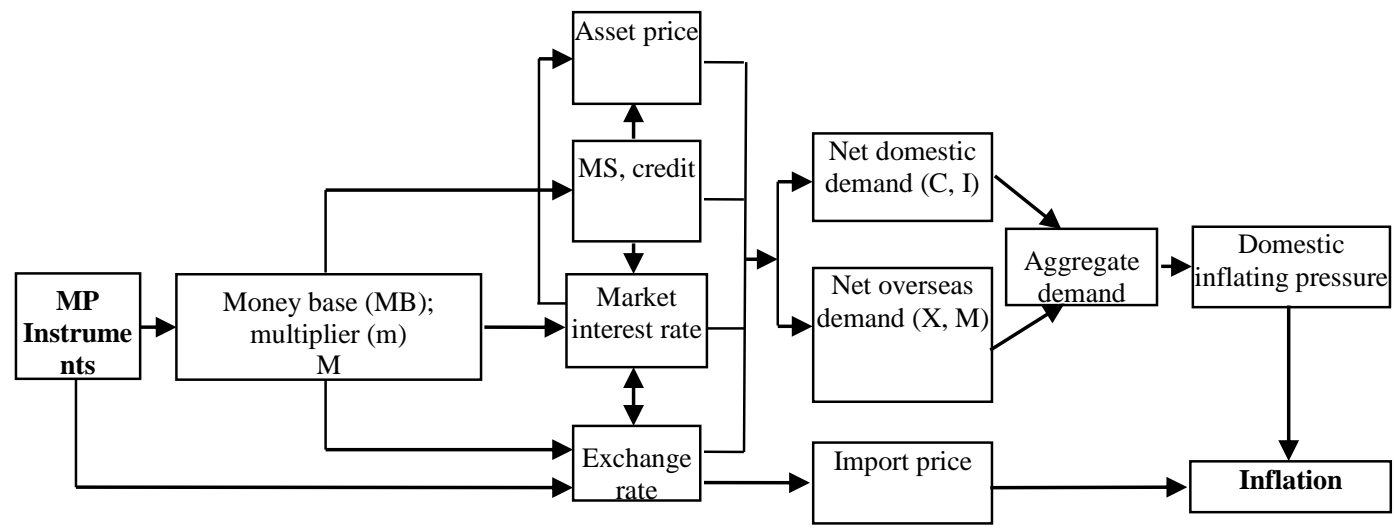

Figure 2: Overall Model of Transmission Mechanism

- Impact of Integration and Demand for Reform in Monetary Policy Implementation by SBV:

International integration may be understood as a process in which countries conduct activities to enhance cohesion based on their struggle for common benefits, goals, values, resources, power (authority to make policies) and compliance with general rules within international institutions or organizations. Thus, unlike international cooperation - action taken by international agents to satisfy needs or aspirations of one another without opposition - international integration goes beyond common international cooperation: it requires sharing willingness and discipline by participants.

Connotations of international integration: International integration can take place in a single field of social life (economy, politics, national security and defense, culture, education, social affairs, etc.) but can also occur simultaneously in various fields with very different features (i.e. degree of cohesion), scope (territory, sector/field) and forms (bilateral, multilateral, regional, inter-regional, global one).

Integration in the monetary and banking sector is a process of gradually implementing liberalization of finance, currency and banking service, which is a process of flexibly regulating domestic monetary and financial system by means of indirect tools compliant with the laws and international rules. In this process, barriers to regional and international financial and monetary markets will be gradually eliminated; and direct intervention by governments and agencies in this sector will be reduced.

- Impact of Financial Liberalization on Transmission Mechanism of Monetary Policy: 
+ The liberalization of financial markets has an impact on the balance of payments, exchange rate and interest rate equilibrium, thus hindering the central bank's control over money supply, interest rate and exchange rates.

+ Economic integration increases the depth of financial markets, the diversity and competitiveness of financial intermediaries, which would alter the effect of transmission mechanism through the channels.

+ Reducing the government's intervention in the financial system in forms of assigning credit (supplying loans as directed by the central government) and credit limit and controlling interest rates would reduce the importance of credit channels but increase that of interest rate channels.

+ The national monetary policy is always affected by changes in monetary policies in foreign countries.

\section{b. Methods:}

Various data analysis methods corresponding to different targets and research contents are employed in the research, including the followings:

* Descriptive statistics features such indexes as mean, maximum, minimum, and standard deviation. These statistical values present characteristics of data. The method is used to describe the nature of the studied objects; and combined with the comparative method to achieve the results needed for evaluation.

* Quantitative Methods with Vector Autoregression Model- VAR

The research employs Vector Autoregression model (VAR) to assess the trend and level of interdependence among time series. VAR is a vector model with Autoregression variables. Each variable linearly depends on lagged values of this variable and those of others. According to Sims (1980), VAR is considered a valuable means to examine the dynamic effects of a shock of this variable on another variable, appropriate for testing a process with a variety of time series as it provides various criteria for an optimum length of variables. Moreover, it covers a system of equations that allows the variables to be related to one another and a simultaneous equations system in which all variables are treated as endogenous ones.

It is likely that this is one of the most popular models in quantitative studies of monetary policy since the relationship between economic variables is not simply oneway, i.e. independent variables (explanatory ones) affects dependent variables, but in 
many cases the relationships are two-way. For this reason, a reciprocal interaction between these variables should be simultaneously examined and VAR model helps solve the matter adequately, being a model quite flexible and easy to be employed in the analysis of multivariate time series.

\section{c. Data and Variables:}

The research makes use of data from the General Statistics Office, annual reports, decisions and directives and official correspondence of SBV, and database of financial indicators from IFS-IMF, and FED in the period 1990-2012.

Empirical model: The research evaluates the impact of monetary policy on the economy through the analysis of transmission mechanism. To the best of authors' knowledge and researching effort, there have been many researches conducted both domestically and internationally on the same issue in the past decades.

We can draw from published studies some concepts that researchers have discovered and tested separately, including GDP, CPI, M2, exchange rates, refinancing interest rates, credit limits, world CPI (WCPI), world oil price (WOil), world rice price (WRice), and U.S. federal funds rate (FFR). In particular, the variables WCPI, WOil, WRice, and FFR are included in the model as exogenous ones to control external shocks, taking into account the economic openness of Vietnam and the use of VND/USD rate as a pegged exchange rate in monetary policy of Vietnam. In addition, required reserve ratio, a direct tool that SBV used for implementing its monetary policy in recent years, has also been closely examined when assessing impacts of macroeconomic variables, yet there is no research on specific measurement of the impact level as well as its transmission power in monetary policy implementation in Vietnam.

Table 1: Variables in the VAR Model

\begin{tabular}{llll}
\hline \multicolumn{1}{c}{ Variable } & Abbr. & Period (Quarter) & Source \\
\hline Domestic sector: & & & \\
Output & GDP & 1990 Q1-2011Q3 & IFS-IMF \\
Domestic CPI & CPIVN & 1990 Q1-2011Q3 & IFS-IMF \\
Money Supply M2 & M2 & 1990 Q1-2011Q3 & IFS-IMF \\
\hline Monetary transmission channels & & & \\
Exchange rate & EX & 1990 Q1-2011Q3 & NHNN
\end{tabular}




\begin{tabular}{|c|c|c|c|}
\hline Refinancing rate & INTEREST & 2000Q1-2011Q3 & NHNN \\
\hline Credit limit & HMTD & 1990Q1-2012Q3 & NHNN \\
\hline Required reserve & DTBB & 1990Q1-2012Q3 & NHNN \\
\hline \multicolumn{4}{|l|}{ International sector: } \\
\hline World CPI & CPIW & 1990Q1-2012Q3 & IFS-IMF \\
\hline World oil price & WOil & 1990Q1-2012Q3 & IFS-IMF \\
\hline World rice price & WRice & 1990Q1-2012Q3 & IFS-IMF \\
\hline U.S. federal funds rate & FFR & 1990Q1-2012Q3 & FED \\
\hline
\end{tabular}

(Where NHNN: SBV; IFS-IMF: IMF database of financial indicators; FED: U.S. Federal Reserve System)

Source: Author's synthesis

\section{RESULTS AND DISCUSSION}

Table 2: Descriptive Statistics of Variables

\begin{tabular}{|c|c|c|c|c|c|c|c|c|c|}
\hline & M2 & GDP & HMTD & EX & INTEREST & OIL & FFR & CPIVN & CPIW \\
\hline Mean & 1313396. & 116301.6 & 23.74194 & 16986.39 & 7.403226 & 67.28806 & 2.141935 & 11.10682 & 4.615439 \\
\hline Median & 1254000 & 115119.0 & 25.00000 & 16114.00 & 6.500000 & 64.63000 & 1.800000 & 8.728349 & 4.338351 \\
\hline Maximum & 2673760. & 167520.0 & 30.00000 & 20703.00 & 14.00000 & 124.2600 & 5.300000 & 27.90153 & 10.34030 \\
\hline Minimum & 404093.0 & 71080.00 & 20.00000 & 15723.00 & 5.000000 & 29.46000 & 0.100000 & 2.394376 & 1.103433 \\
\hline Std. Dev. & 732400.0 & 24373.72 & 3.193407 & 1562.876 & 2.233903 & 23.96202 & 2.054227 & 76.461752 & 1.998953 \\
\hline Skewness & 0.428388 & 0.129536 & 0.575790 & 1.327260 & 1.819133 & 0.614321 & 0.391656 & 51.302228 & 1.248436 \\
\hline Kurtosis & 1.863686 & 2.243223 & 2.571788 & 3.493485 & 6.079546 & 2.861370 & 1.535588 & 3.715513 & 4.708705 \\
\hline Jarque-Bera & 2.615979 & 0.826447 & 1.949774 & 9.416256 & 29.34743 & 1.974673 & 3.562521 & 19.422908 & 11.82397 \\
\hline Probability & 0.270363 & 0.661515 & 0.377235 & 0.009022 & 0.000000 & 0.372568 & 0.168426 & 50.008992 & 0.002707 \\
\hline Sum & 40715275 & 3605350 & 736.0000 & 526578.0 & 229.5000 & 2085.930 & 66.40000 & 344.3114 & 143.0786 \\
\hline $\begin{array}{l}\text { Sum Sq. } \\
\text { Dev. }\end{array}$ & $1.61 \mathrm{E}+13$ & $1.78 \mathrm{E}+10$ & 305.9355 & 73277419 & 149.7097 & 17225.35 & 126.5955 & 1252.6271 & 119.8744 \\
\hline Observations & & 31 & 31 & 31 & 31 & 31 & 31 & 31 & 31 \\
\hline
\end{tabular}

Source: Authors' calculations 
Given descriptive statistics of the variables in the model, in general, most of them are right-skewed, which is typical of time series data, and kurtosis values vary around the standard value, with INTEREST coming up with the highest one, achieving the lowest deviation, and M2 having the highest deviation. Jarque-Bera test reveals that most of the variables, except for EX and INTEREST, have normal distribution.

\section{Model 1: Money Supply, Output and Inflation}

To examine the relationship between money supply, domestic output, and inflation, VAR is applied with such endogenous variables as GDP, CPIVN, EX, and M2 along the lag value of 5 according to LR, FPE, AIC, and HQ.

Table 3: Results of VAR Lag Order Selection

VAR Lag Order Selection Criteria

\begin{tabular}{ccccccc}
\hline Lag & $\log \mathrm{L}$ & $\mathrm{LR}$ & FPE & AIC & SC & HQ \\
\hline 4 & -1184.133 & 77.22830 & $1.25 \mathrm{e}+15$ & 43.23275 & $44.95321^{*}$ & 43.90138 \\
5 & -1168.830 & $20.40504^{*}$ & $1.04 \mathrm{e}+15^{*}$ & $43.01156^{*}$ & 45.05462 & $43.80556^{*}$ \\
\hline
\end{tabular}

Source: Authors' calculations

Next, to determine whether M2 affects GDP and CPIVN or not, an impulse response analysis is conducted to measure the shock from M2 to GDP and CPIVN. Figure 3 shows that the impact of M2 shocks on GDP is very weak or they even exert no impact. In the reverse direction, GDP shocks impact significantly on the M2 and they are persistent through the cycles, which suggests that changes in output are the cause of monetary expansion in Vietnam. 

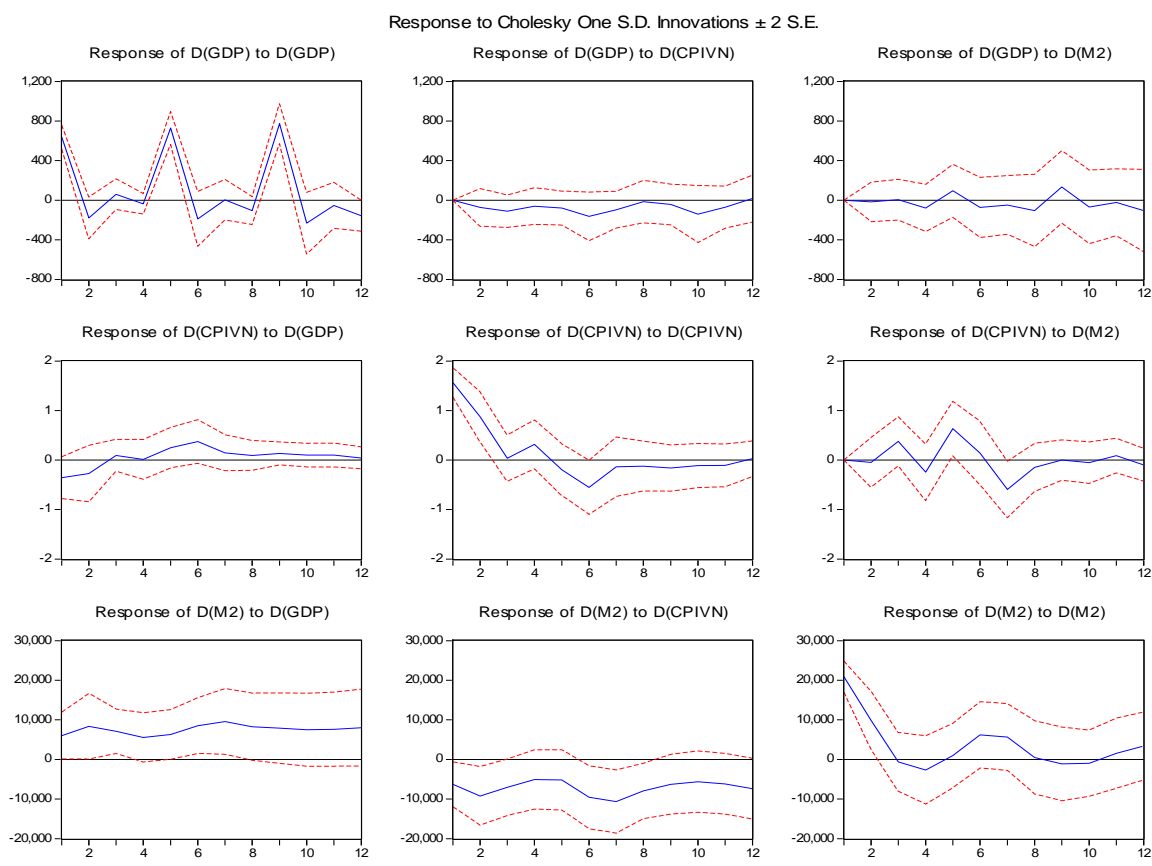

Figure 3: Results of Impulse Response of Model 1

Source: Author's calculations

Figure 3 also indicates that shocks in the change in M2 do impact CPIVN and persist in the next eight cycles; a sudden increase in money supply will boost CPIVN in the early stage and then drop gradually and become stabilized. In contrast, a sudden increase in CPIVN results in the central bank's monetary tightening and an immediate reduction in M2; this policy is also maintained throughout the cycles that follow to control the inflation.

To learn more about the explanatory power of variables in the same model, variance decomposition method is employed. Results showed that M2 explains only $3 \%$ of change in GDP, compared with $4 \%$ in the case of CPIVN.

Meanwhile, M2 explains up to $20 \%$ of change in CPIVN compared with $9 \%$ achieved by GDP, which more firmly indicates the sharp impact of the rise in M2 on inflation in Vietnam, compliant with previous monetary theories.

In reverse, among the variables, GDP possibly best explains the volatility in M2; the second is CPIVN, which suggests that the current monetary policy features a high 
latency: adjustments are only made when output declines or inflation rises and simply as countermeasures without the ability to predict and to be consistent with the actions in the medium and long term. Jerky and seasonal implementation of the policy is the root of instability in the financial and monetary market in recent times.

\section{Model 2: Impact of Exchange Rate on Output and Inflation}

For further clarification of the impact of monetary policy on output and inflation, the original model of the study is complemented by instrument variables.

Initially, EX (exchange rate) is added. Similar to the above model, the research employs the lag value 5 according to the criteria LR, FPE, AIC, and HQ to perform VAR.

Table 4: Lag Order Selection for VAR Model

\begin{tabular}{ccccccc}
\hline Lag & LogL & LR & FPE & AIC & SC & HQ \\
\hline 4 & -1549.014 & 66.01562 & $8.87 \mathrm{e}+19$ & 57.15839 & $60.02584 *$ & 58.27278 \\
5 & -1525.511 & $27.21467 *$ & $7.52 \mathrm{e}+19 *$ & $56.89511^{*}$ & 60.33604 & $58.23237 *$ \\
\hline
\end{tabular}

Source: Author's calculations

The robustness of the model is examined using LM tests with the hypothesis $\mathrm{H}_{0}$ assuming that no autocorrelation exists between the residuals in the model. The results show that $\mathrm{P}$-value is greater than 0.05 , which implies that the hypothesis $\mathrm{H}_{0}$ is acceptable and the regression model is appropriate. 

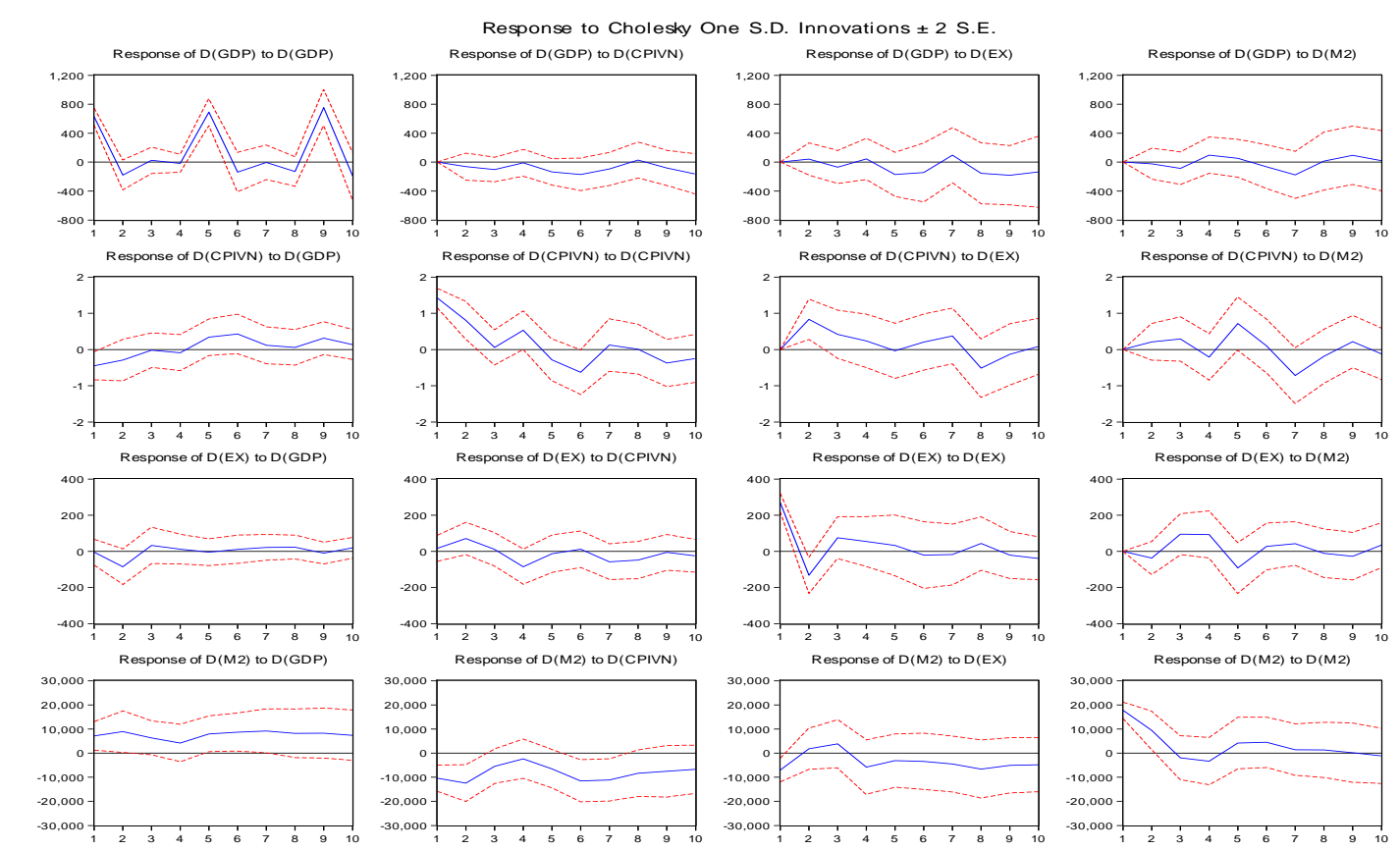

Figure 4: Results of Impulse Response Analysis in Model 2

Source: Author's calculations

The impulse response is performed to examine how exchange rate shocks impact the remaining variables in the model. Figure 4 illustrates a seemingly very low impact on the change of national output: the response line revolves around the axis 0 . Meanwhile, exchange rate impact makes CPIVN increase after two cycles and then the impact lingers and reduces gradually in the next cycles. This suggests that any upheaval in exchange rate will have an effect on inflation after one quarter, and any increase in the rate will affect inflation shortly thereafter.

Furthermore, exchange rate shocks would persuade the government to reduce the money supply to immediately stabilize the rate and control the inflation, and effects of the shocks will have the money supply maintained at reduced levels in the next cycles, i.e. Its effects last a long time.

Results of variance decomposition of variables in the regression model also suggest that exchange rate explains only $7 \%$ of change in the GDP, which is best explained by its intrinsic movement, up to $82 \%$. In addition, the exchange rate is considered an important cause of CPI change in Vietnam, with an explanatory power up to $20 \%$. In a 
reverse case, the money supply is recognized as the main cause of change in exchange rate apart from itself, with an explanatory of $19 \%$.

The results of the variance decomposition also reveal that although exchange rate can explain only $7 \%$ of change in the GDP and $11 \%$ of change in the money supply, it can account for $20 \%$ of changes in the CPIVN, which implies that the exchange rate is one of main causes of changes in Vietnam's inflation rate.

\section{Model 3: Impact of Refinancing Interest Rate on Output and Inflation}

Refinancing interest rate is another variable added to the model to analyze the impact of this instrument on the economic indicators. Four lags are selected according to LR, FPE, AIC, SC, and HQ. The regression model confirms its robustness as no autocorrelation could be found in LM tests.
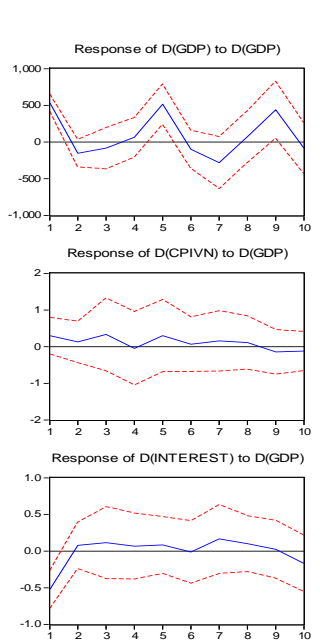

Response of $\mathrm{D}(\mathrm{MR})$ to $\mathrm{D}(\mathrm{GDP})$

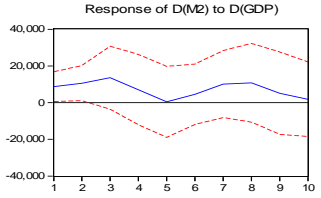

Response to Cholesky One S.D. Innovations \pm 2 S.E.
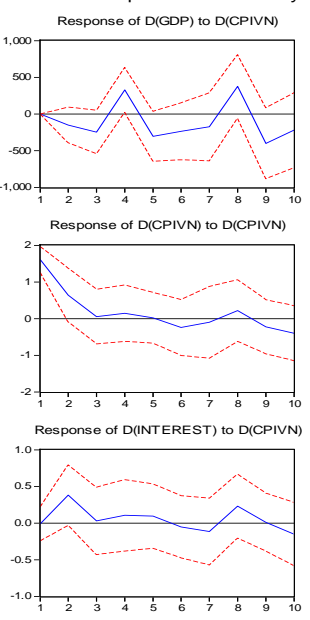

Response of $\mathrm{D}(\mathrm{MR})$ to $\mathrm{D}(\mathrm{CPIVN})$

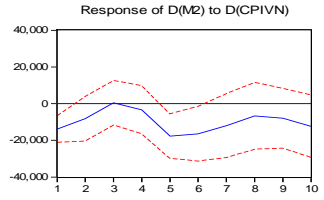

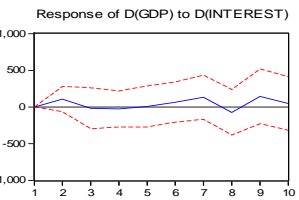
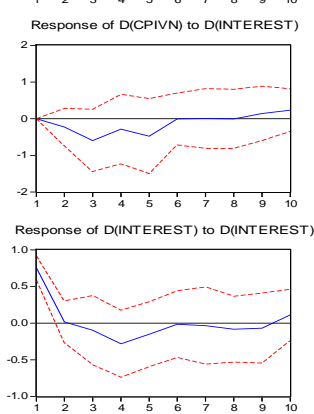

Response of D(NR) to D(INTEREST)

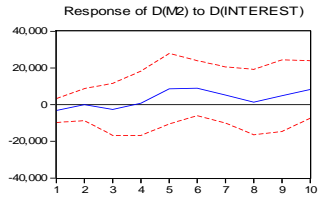

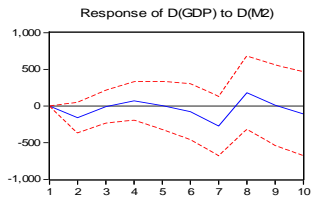

Response of $\mathrm{D}(\mathrm{CPIVN})$ to $\mathrm{D}$ (NR)
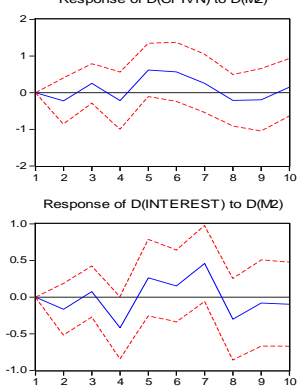

Response of $\mathrm{D}(\mathrm{MR})$ to $\mathrm{D}(\mathrm{M})$

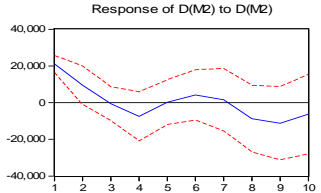

Figure 5: Results of Impulse Response Analysis in Model 3

Source: Author's calculations

The results of the impulse response analysis in Figure 5 show that refinancing interest rate is not a cause of GDP change, whereas interest rate shocks exert instant effects on 
CPIVN - a rise in interest rate decreases CPI in the short run, being compliant with previous theories and researches on this instrument by SBV.

The results of the variance decomposition analysis also indicates that refinancing interest rate explains only 3\% of GDP volatility, and its impact is at a medium level of $14 \%$, which implies that refinancing instruments in recent times have yet to achieve their efficiency, and a change in money supply is one of the main causes leading to that in refinancing interest rate.

\section{Model 4: Impact of Credit Limit on Output and Inflation}

Since credit limit has only come into effect from 2004, the number of observations is limited, only consisting of 28 . The appropriate lag value selected in the model, therefore, is 1 in order to minimize the decrease in degree of freedom.

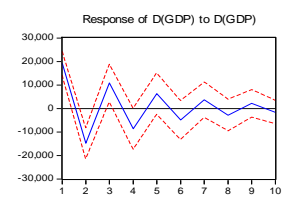

Response of D(CPIVN) to D(GDP)

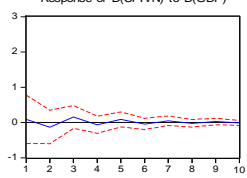

Response of D(HANMUCTINDUNG) to D(GDP)
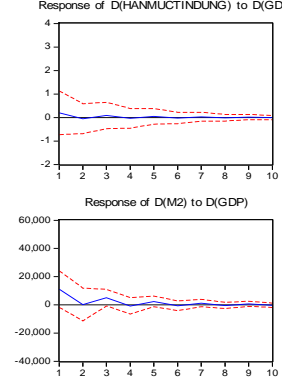

Response to Cholesky One S.D. Innovations \pm 2 S.E.

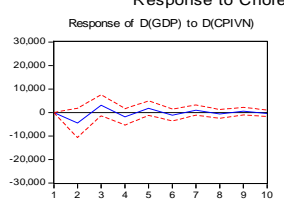

Response of D(CPIVN) to D(CPIVN)
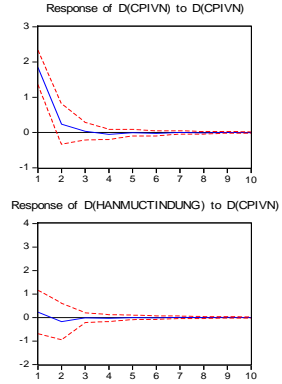

Response of $D(M 2)$ to D(CPIVN)

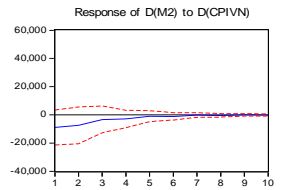

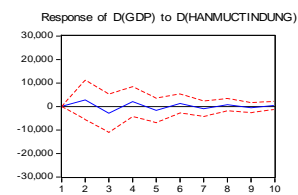

Response of DicPiven to Ditummuctindunce

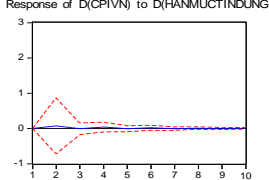

Response of D(HANMUCTINDUNG) to D(HANMUCTINDUNG)
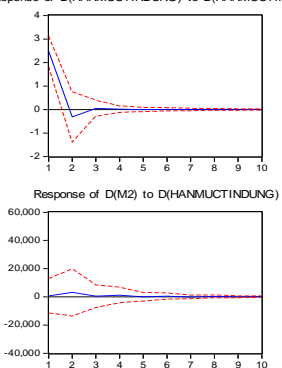

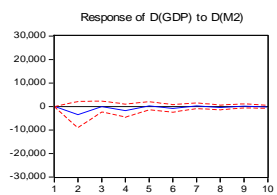

Response of $\mathrm{D}(\mathrm{CPIVN})$ to $\mathrm{D}(\mathrm{M} 2)$

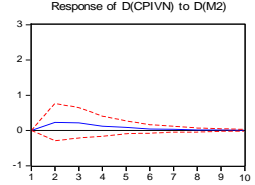

Pesponse of D(HANmuctindung) to Dina
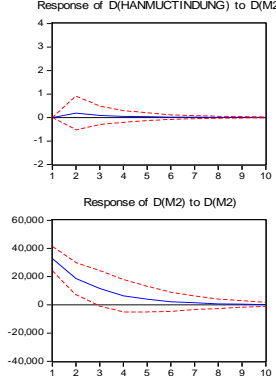

Figure 6: Results of Impulse Response Analysis in Model 4

Source: Author's calculations

Figure 6 illustrates that credit limit shocks introduced by SBV have no impact on such macroeconomic variables as GDP and CPI (all response lines horizontally corresponds to 0 ); thus, credit limit employed as an instrument proves inefficient. 
That would be further clarified by the results of the variance decomposition analysis: credit limit only explains $2 \%$ of GDP change and $0.2 \%$ of CPIVN change, the lowest rate achieved by a single instrument among others surveyed in the research.

\section{Model 5: Impact of required reserve on output and inflation}

In case of required reserve preferred as replacement for credit limit, the lag value of 4 is applied according to LR, FPE, AIC, SC, and HQ.

Test of relationships between residuals provides no evidence of autocorrelation among them, ensuring the efficiency of the model for estimations.

The results of the impulse response analysis in Model 5 suggest that required reserve shocks create a rather significant impact on the change in output of the economy, which is maintained quite a long period over the surveyed cycles. Moreover, its effect on CPI counts, proceeding until the $6^{\text {th }}$ cycle and then ceases altogether.
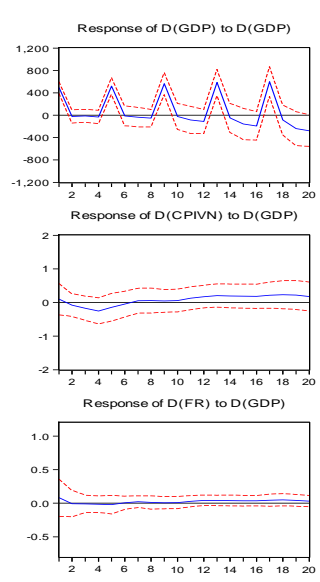

Response of $\mathrm{D}(\mathrm{M}$ 2) to $\mathrm{D}(\mathrm{GD})$

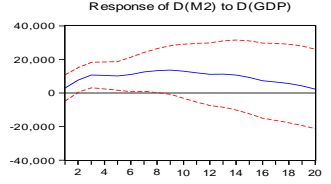

Response to Cholesky One S.D. Innovations \pm 2 S.E.
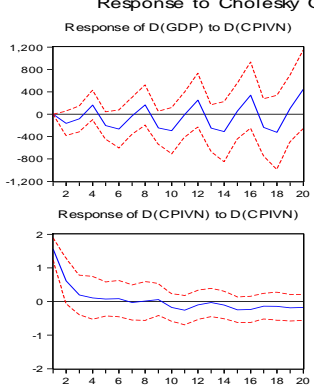

Response of D(FR) to D(CPIVN)

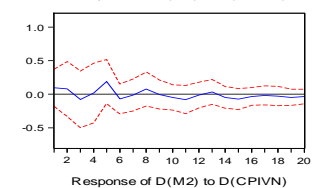

Response of $D$ (M2) to D (CPIVN)

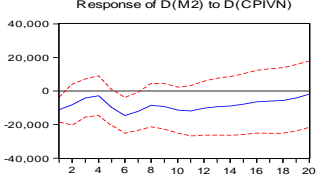

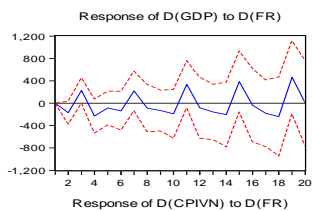

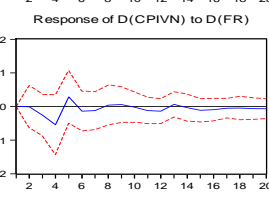

Response of $\mathrm{D}$ (FR) to $\mathrm{D}(\mathrm{FR})$

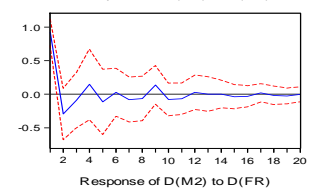

Response of $\mathrm{D}(\mathrm{M} 2)$ to $\mathrm{D}(\mathrm{FR})$

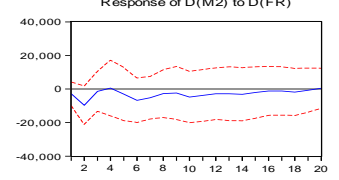

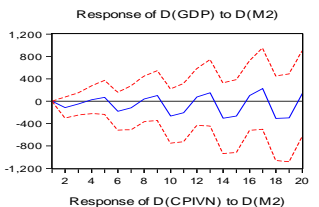

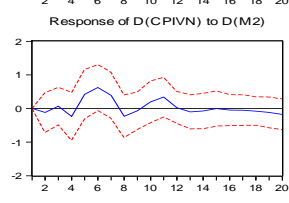

Response of $D(F R)$ to $D$ (M2)
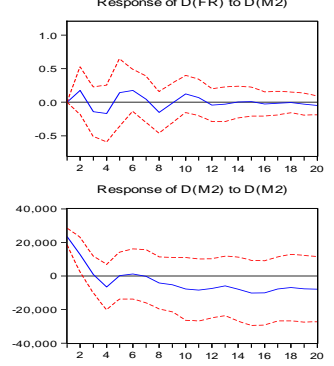

Figure 7(11): Results of Impulse Response Analysis in Model 5

Source: Author's calculations

The results of the variance decomposition analysis in 20 cycles indicates that required reserve explains $20 \%$ of GDP change, the highest rate achieved by an instrument among others, and is considered as an effective instrument for boosting the national output. On 
$\mathrm{CPI}$, required reserve has a slight impact, explaining only $10 \%$ of its volatility over 20 cycles.

In sum, monetary policy in Vietnam in the past was not truly effective as changes in the money supply could not affect substantially such variables as output and inflation. In particular, the impact of monetary policy on economic growth is slight and its main impact is found in inflation control, which is not truly high either. Among monetary policy instruments, exchange rate and refinancing rate are considered to play a role in controlling inflation; required reserve does affect economic growth in Vietnam, whereas the research finds no evidence of impact caused by credit limit on macro variables.

The research results are fully in accordance with fundamental theories of economics on monetary policy. Mulldel - Fleming model indicated that in terms of such a small, open economy with less flexible policy on exchange rate as Vietnam, monetary policy is likely to be neutralized and can hardly produce intended effects. On the contrary, the fiscal policy is more appropriate in such economic conditions.

\section{CONCLUSION}

\section{a. Achievements:}

In general, since the 1997 financial crisis, SBV has gradually proceeded with dramatic changes in its monetary policy and selection of appropriate mechanisms in conformity with characteristics and scale of the economy as well as each stage of development.

Identification of the ultimate goals for monetary policy is increasingly effective, reflected through their feasibility and is under complete control of SBV, not as previously defined in 1997 SBV Law. In conducting the policy over the past years, SBV was right to 'stabilize' various economic variables because cautious steps when integrating into the world market and developing the domestic infant monetary and capital markets are very important.

The instruments for SBV's monetary policy implementation are developed rather well and the SBV is moving to the use of indirect instruments instead of direct ones; refraining from employing administrative orders. Interest rate and exchange rate mechanisms in Vietnam have gradually been reformed in the direction of boosting the level of liberalization while changes in regulations on borrowing and lending rates as well as the level of "floating" in determining the exchange rate and its fluctuation bands are constantly adjusted and expanded. 
A series of actions from setting specific rates to free agreements indicate that interest rate and exchange rate policy of the central bank changes flexibly, in line with the trend of integration and domestic economic conditions. Harmonious combination between open market operations and flexible interest rate policy are accompanied to simultaneously solve two problems, ensuring reasonable funds for business development and economic growth, and preventing the danger of overheating and high inflation.

\section{b. Shortcomings:}

In monetary policy implementation, the SBV has focused too much on economic growth and neglected inflation control, that is, accepting a high inflation rate to achieve the economic growth, as evidenced by a small difference between the planned target for economic growth and the actual growth rate but a too large one regarding the inflation target. This results in many uncertainties in the long term as analyzed in above sections. Moreover, efforts to use the monetary policy to serve the economic growth as the top target prove inefficient since the growth in money supply produces high inflation rates rather high growth rate as illustrated by Model 1.

During recent years, the SBV has returned to the use of several administrative measures in monetary policy implementation to reduce inflation and stabilize currency values. It is likely, according to the SBV's view, that regulations on interest rate ceiling or credit growth limit are just a temporary solution to prevent weak banks from performing irrational business activities. However, consequences of such administrative measures would distort the currency market, and cause difficulties for operation of healthy banks.

In addition, according to Nguyễn (2008), the SBV latest inflation controlling policy has yet to target the root cause. Apart from a number of such internal causes such as natural disasters, rampant investment in some unproductive projects, the main cause of high inflation in Vietnam is shortcomings in the direction for policy on external shocks, especially the exchange rate policy. An exchange rate policy that fails to cope with upheavals in the world economy leads to huge increases in the money supply and domestic production cost - two main causes of high inflation rates in Vietnam. It happens as follows:

(1) Exchange rate firmly pegged to the USD makes the money supply increase, and (2) Being pegged to a globally depreciated US dollar increases domestic production cost. A policy to make the VND weak may boost export but it contributes to 'import' of 
inflation to Vietnam. The reason is that production in Vietnam is greatly dependent on such imported materials as petroleum, cement, iron and steel, machinery, and so on. The depreciation of the USD, or in other words, the appreciation in the cost of imported items essential for production in VNĐ governed by exchange rate anchor is a major cause leading to the increase in domestic production cost and, subsequently, in commodity prices. Hyperinflation is, therefore, inevitable, which corresponds to the findings from Model 2 indicating that exchange rate is one of the root causes of inflation in Vietnam. Furthermore, pegging the domestic currency to a hard one restrains the ability to use the exchange rate as a tool for achieving macroeconomic goals.

SBV's ability to predict inflation is still weak since the band between actual inflation and target inflation rates is wide and adjusted many times a year. In addition, the results from Model 1 also show that monetary policy in Vietnam currently feature high latency because the monetary policy is used for dealing with falls in output or rises in inflation rate and the SBV fails to make predictions as well as consistent implementation of monetary policy in the medium and long term, as demonstrated by Model 1 .

Overall, the research results showed that monetary policy in Vietnam in the past was not truly effective, which reveals itself in the fact that changes in money supply did not produce strong effects on such variables as inflation and gross output (results from Model 1).

The results from the remaining models indicated that among instruments for the monetary policy, exchange rate and refinancing rate are considered important to the effort to curb inflation, and required reserve has great effects on economic growth, while the research finds no evidence of effects of credit limit set by the SBV on macroeconomic variables

\section{References}

Burton, M. \& B. Brown (2009), The Financial System and the Economy: Principles of Money and Banking, $5^{\text {th }}$ ed., M.E.Sharpe.

European Central Bank (2013), "European Central Bank's monetary policy", available at http://thismatter.com/money/banking/european-central-bank-monetary-policy.htm, retrieved on Aug. 1, 2013.

Friedman, M. (1968), “The Role of Monetary Policy”, American Economic Review, Vol. 58(1), pp.117. 
González, J.A. (2003). "Exchange Rate Pass-through and Partial Dollarization: Is There a Link?", Stanford University, SCID Working Paper, pp.79-106.

Haldane, A. \& V. Read (2000), "Monetary Policy Surprises and the Yield Curve”, Bank of England, Working Paper No. 106.

Krugman, P. (1979), “A Model of Balance-of-Payments Cries”, Journal of Money, Credit and Banking, Vol.11(3), pp.311-325.

Krugman. P. \& M. Obstfield (1996), Kinh tế học quốc tế, lý thuyết và chính sách, Chính Trị Quốc Gia Publisher.

Kuttner, K.N. (2002), "Monetary Policy Surprises and Interest Rates: Evidence from the Fed Funds Futures Market, Journal of Monetary Economics, Vol. 47(3), pp.523-544.

Mishkin, F.S. (1996), "The Channels of Monetary Transmission: Lessons for Monetary Policy", Banque de France Bulletin Digest, Working Paper No. 5464.

Nguyễn Phi Lân (2010), “Cơ chế truyền dẫn tiền tệ dưới góc độ phân tích định lượng”, Ngân hàng, (18), pp.19-27.

Nguyễn Quốc Hùng (2008), “Chống lạm phát bằng chính sách tỷ giá: Một công cụ mạnh cần được phát huy hiệu quả hơn", Tia Sáng, available at http://tiasang.com.vn/Default.aspx?tabid=114\&CategoryID=7\&News=1634, retrieved on Nov. 12, 2013.

Nguyễn Thị Kim Thanh (2010), “Ảnh hưởng của đôla hóa đến thực thi chính sách tiền tệ của Ngân hàng nhà nước Việt Nam”, Ngân hàng, (23).

SBV (2013), "Văn bản quy phạm pháp luật”, available at http://www.sbv.gov.vn/portal/faces/vi/vim/vipages_trangchu/vbqppl/vanbanmoi?_adf.ctrlstate=15ivrr80z_4\&_afrLoop=6567415708102900, retrieved Nov. 12, 2013

Sims, C.A. (1980), "Macroeconomics and Reality”, Econometrical, Vol. 48(1), pp.1-48.

Smitha, T.H. (2010), Impact of Monetary Policy on Indian Economy in the Post-Reform Period, Dissertation of Doctor of Philosophy, Cochin University of Science and Technology.

Thornton, D.L. (1998), "Tests of the Market's Reaction to Federal Funds Rate Target Changes", Federal Reserve Bank of St. Louis Review, 80(6), pp.25-36.

Tô Kim Ngọc \& Lê Thị Tuấn Nghĩa (2012), "Phối hợp chính sách tiền tệ và chính sách tài khóa ở Việt Nam", Ngân hàng, (11), pp.2-9.

Trần Ngọc Thơ \& Nguyễn Ngọc Định (2012), Tài chính quốc tế, Kinh Tế Publisher.

Trương Văn Phước \& Chu Hoàng Long (2005), "Chỉ số giá tiêu dùng và các yếu tố tác động: Phương pháp tiếp cận định lượng”, Thông tin khoa học thống kê (4). 